\title{
To evaluate the efficacy and safety of single dose intravenous iron carboxymaltose verses multidose iron sucrose in post-partum cases of severe iron deficiency anemia
}

\author{
Urvashi Verma*, Saroj Singh, Mukul Chandra, Mukesh Chandra, \\ Ruchika Garg, Shikha Singh, Renu Rajvansh
}

Department of Obstetrics \& Gynaecology, S. N. Medical College, Agra, Uttar Pradesh, India

Received: 10 February 2015

Accepted: 01 March 2015

*Correspondence:

Dr. Urvashi Verma,

E-mail: drurvashiverma@ rediffmail.com

Copyright: () the author(s), publisher and licensee Medip Academy. This is an open-access article distributed under the terms of the Creative Commons Attribution Non-Commercial License, which permits unrestricted non-commercial use, distribution, and reproduction in any medium, provided the original work is properly cited.

\begin{abstract}
Background: Iron deficiency is the most common nutritional deficiency worldwide. Anemia is the most common treatable, direct/indirect cause of maternal and neonatal morbidity and mortality in developing countries like India.

Methods: 100 cases with iron deficiency anemia in post-partum patient were selected from postpartum wards and assigned in two groups of 50 each. In group A iron carboxymaltose injection administered by intravenous infusion up to a maximum single dose of $20 \mathrm{ml}$ of iron carboxymaltose injection (1000 $\mathrm{mg}$ of iron). In group B Iron sucrose was given as $200 \mathrm{mg}$ elemental iron ( 2 ampules of $5 \mathrm{ml}$ ) in $100 \mathrm{ml}$ of $0.9 \%$ normal saline infusion over 15 min alternate days up to 5 days. All patients were monitored for rise in hemoglobin level and any adverse effect at 2 weeks, 4 weeks, 8 weeks and 12 weeks of iron therapy.

Results: In group A mean Hemoglobin level rise is $3.95 \mathrm{~g} / \mathrm{dl}$ and in group B it is $3.32 \mathrm{~g} / \mathrm{dl}$ at 4 weeks of initial therapy. In group A $100 \%$ cases achieved target hemoglobin at 12 weeks after therapy while in group B $98 \%$ cases achieved target hemoglobin at 12 weeks after therapy. In group A $12 \%$ cases have grade 1 adverse reaction while in group B 20\% cases have adverse reaction.

Conclusions: Administration of intravenous iron has a good clinical result, with minimum adverse reactions. Thus we can conclude that intravenous ferric carboxymaltose therapy is safe, convenient, more effective and faster acting than intravenous iron sucrose for treatment of severe iron deficiency anemia in postpartum patient.
\end{abstract}

Keywords: Ferric carboxymaltose, Iron sucrose, Iron deficiency anemia, Hemoglobin

\section{INTRODUCTION}

Iron deficiency is the most common nutritional deficiency worldwide; it affects 1.6 billion people (nearly a quarter of the world's population). ${ }^{1}$ Lack of iron supplementation during pregnancy and postpartum hemorrhage $(\mathrm{PPH})$ are another important causes of postpartum anemia (PPA). Randomized clinical trials have shown that lack of prenatal iron supplementation is associated with low ferritin stores throughout the postpartum period. ${ }^{1}$ This is because pregnancy requires about $1000 \mathrm{mg}$ of additional iron, which cannot be met by the typical diet. ${ }^{2,3}$ These women with Iron Deficiency Anemia (IDA) especially during the second and third trimester of pregnancy are more likely to suffer from postpartum hemorrhage (PPH) and further worsen anaemia and its related complications. PPH is also an important cause of postpartum anemia. ${ }^{4}$

Peri partum iron deficiency anemia is significant cause of maternal, fetal as well as infants morbidity and mortality.(a) Over the past years various routine methods like oral iron, intramuscular iron and blood transfusions were used to treat anemia during postpartum period, but 
these methods have some defiencies. ${ }^{5-7}$ Orally given iron has side effects like intolerance, nausea, vomiting, epigastric pain, diarrohea, constipation, unpredictable absorption rate and poor compliance. ${ }^{8}$

Iron was given intramuscularly cause considerable pain, skin staining, bleeding, tissues necrosis, arthralgia, myalgia, sterile abscess atrophy and sarcoma formation.

So to treat these conditions we require a new mode of iron therapy with better efficacy, less side effects and better compliance. Intravenous iron carboxymaltose therapy seems to be a safe, convenient and more effective method for treating anemia during postpartum period than intravenous iron sucrose therapy. ${ }^{8}$

Aims and objective: Comparative study of efficacy and safety of single dose intravenous iron carboxymaltose and multi dose intravenous iron sucrose therapy in postpartum women of sever iron deficiency anemia.

\section{METHODS}

Study was carried out in the department of obstetrics and gynaecology, S. N. medical college Agra during 2 year duration from October 2012 to October 2014.

The study comprised of 100 cases which are to be randomly distributed into two groups consisting of 50 cases each.

Group - A: 50 cases in this group receive intravenous iron carboxymaltose therapy.

Group - B: 50 cases in this group receive intravenous iron sucrose therapy.

\section{Inclusion criteria}

All normal delivered and caesarean delivered patients with IDA

Exclusion criteria-

- Patients with hemoglobin levels more than $7 \mathrm{gm} \%$.

- Normal serum iron levels.

- Patients with history of allergic reactions to previous iron therapy.

- Severe asthma/allergy

- Patients with other causes of anaemia like:

Liver diseases

Renal disease

\section{Calculation of total iron requirement}

Iron deficit was calculated by the formula:

Total iron deficit $=$ Iron deficit + amount of iron

Required to replenish stores:

Iron deficit $(\mathrm{mg})=$ Body weight $(\mathrm{kg}) \times$ Hb deficit $\times 0.3$

$\mathrm{Hb}$ deficit $=$ Target $\mathrm{Hb}$ - Initially measured $\mathrm{Hb}$

Target $\mathrm{Hb}$ concentration $=11 \mathrm{gm} \%$

Iron required to replenish $=$ Body weight $(\mathrm{kg}) \times 10$ stores (mg)

Total iron dose required $(\mathrm{mg})=2.4 \times$ Body weight $(\mathrm{kg}) \times$ (Target $\mathrm{Hb}-$ Actual $\mathrm{Hb}$ in $\mathrm{g} / \mathrm{dl}$ ) $+500 \mathrm{mg}$.

\section{Iron therapy}

Group A: Intravenous injections (Iron carboxymaltose complex)

They are available as ampules of $10 \mathrm{ml}$ containing 500 $\mathrm{mg}$ of elemental iron. Ferric carboxymaltose injection administered as follows:

Table 1: Intravenous injections (Iron carboxymaltose complex).

\begin{tabular}{|c|c|c|c|}
\hline $\begin{array}{l}\text { Ferric } \\
\text { carboxymaltose }\end{array}$ & Iron & $\begin{array}{l}\text { Maximum } \\
\text { amount of } \\
\text { sterile } \\
0.9 \% \mathrm{NaCl} \\
\text { solution }\end{array}$ & $\begin{array}{l}\text { Minimum } \\
\text { administration } \\
\text { time }\end{array}$ \\
\hline 10 to $20 \mathrm{ml}$ & $\begin{array}{l}500 \text { to } \\
1000 \\
\mathrm{mg}\end{array}$ & $250 \mathrm{ml}$ & 15 minutes \\
\hline
\end{tabular}

Group B: Intravenous injections (iron sucrose complex)

Iron sucrose complex was given as $200 \mathrm{mg}$ elemental iron (2 ampules of $5 \mathrm{ml}$ ) in $100 \mathrm{ml}$ of $0.9 \%$ normal saline infusion over $30 \mathrm{~min}$. alternate days up to 5 days.

\section{RESULTS}

The mean age in group $\mathrm{A}$ was 25.30 years and mean age in group B was 25.56 years (Table 2). In group A $20 \%$ cases were primiparous and $80 \%$ cases were multiparous (Table 4).

Majority of the cases belonged to lower middle status (class 4) according to modified B. J. Prasad classification in both the groups (Table 3 ). 
The mean hemoglobin level before starting therapy in group A was $6.14 \mathrm{gm} / \mathrm{dl}$ and in group B was $6.06 \mathrm{gm} / \mathrm{dl}$ (Table 5), there was an increase of $2.52 \mathrm{gm} / \mathrm{dl}$ in hemoglobin level after 2 weeks of therapy and mean hemoglobin level was $8.66 \mathrm{gm} / \mathrm{dl}$ in group $\mathrm{A}$ and in group $\mathrm{B}$ there was an increase of $1.95 \mathrm{gm} / \mathrm{dl}$ in hemoglobin level and the hemoglobin level was 8.01 gm/dl (Table 6).

This difference further increased at 4 weeks after therapy. The hemoglobin level was $10.01 \mathrm{gm} / \mathrm{dl}$ in group A (rise of $3.95 \mathrm{gm} / \mathrm{dl}$ ) at 4 weeks of therapy and in group B hemoglobin level was $9.38 \mathrm{gm} / \mathrm{dl}$ (rise of $3.32 \mathrm{gm} / \mathrm{dl}$ ) (Table 7).

Table 2: Distribution of cases according to age.

\begin{tabular}{|lllll|}
\hline \multirow{2}{*}{ Age (years) } & \multicolumn{2}{l|}{ Group A } & \multicolumn{2}{l|}{ Group B } \\
\cline { 2 - 5 } & No. & \% & No. & \% \\
\hline$<20$ years & 4 & 8 & 2 & 4 \\
\hline $20-25$ & 30 & 60 & 32 & 64 \\
\hline $26-30$ & 8 & 16 & 10 & 20 \\
\hline $31-35$ & 6 & 12 & 5 & 10 \\
\hline$>35$ years & 2 & 4 & 1 & 2 \\
\hline Total & 50 & 100 & 50 & 100 \\
\hline Mean age & 25.50 & 25.56 \\
\hline
\end{tabular}

Table 3: Distribution of cases according to socioeconomic status.

\begin{tabular}{|lllll|} 
& \multicolumn{2}{c}{ Group A } & \multicolumn{2}{c|}{ Group B } \\
& No. & \% & No. & \% \\
\hline Class-III (Upper middle) & 6 & $12 \%$ & 7 & $14 \%$ \\
\hline Class -IV (Lower middle) & 35 & $70 \%$ & 34 & $72 \%$ \\
\hline Class -V (Poor) & 9 & $18 \%$ & 9 & $18 \%$ \\
\hline
\end{tabular}

Table 4: Distribution of cases according to parity.

\begin{tabular}{|lllll|}
\hline \multirow{2}{*}{ Parity } & \multicolumn{2}{c}{ Group A } & \multicolumn{2}{c|}{ Group B } \\
& No. & \% & No. & \% \\
\hline 1 & 10 & 20 & 12 & 24 \\
\hline 2 & 18 & 36 & 16 & 32 \\
\hline 3 & 10 & 20 & 10 & 20 \\
\hline$>3$ & 12 & 24 & 12 & 24 \\
\hline Total & 50 & 100 & 50 & 100 \\
\hline
\end{tabular}

Table 5: Hemoglobin level before starting therapy.

\begin{tabular}{|lllll|}
\hline Hemoglobin & \multicolumn{2}{c|}{ Group A } & \multicolumn{2}{c|}{ Group B } \\
level (gm/dl) & No. & \% & No. & \% \\
\hline$<4$ & 1 & 2 & 2 & 4 \\
\hline $4-6$ & 13 & 26 & 14 & 28 \\
\hline $6-7$ & 36 & 72 & 34 & 68 \\
\hline Total & 50 & 100 & 50 & 100 \\
\hline Mean & 6.14 & & 6.06 & \\
\hline P value & 0.001 & & \\
\hline
\end{tabular}

Table 6: Hemoglobin level 2 weeks after starting therapy.

\begin{tabular}{|lllll|}
\hline Hemoglobin & \multicolumn{2}{c}{ Group A } & \multicolumn{2}{c|}{ Group B } \\
level $(\mathrm{gm} / \mathrm{dl})$ & No. & \% & No. & \% \\
\hline $5-7$ & 6 & 12 & 9 & 18 \\
\hline $7.1-9$ & 32 & 64 & 29 & 58 \\
\hline $9.1-11$ & 14 & 28 & 12 & 24 \\
\hline Total & 50 & 100 & 50 & 100 \\
\hline Mean & 8.66 & & 8.01 & \\
\hline P value & 0.002 & & \\
\hline
\end{tabular}

Table 7: Hemoglobin level 4 weeks after starting therapy.

\begin{tabular}{|lllll|}
\hline Hemoglobin & \multicolumn{2}{l|}{ Group A } & \multicolumn{2}{l|}{ Group B } \\
level $(\mathrm{gm} / \mathrm{dll})$ & No. & $\mathbf{\%}$ & No. & $\mathbf{\%}$ \\
\hline $5-7$ & - & - & 1 & 2 \\
\hline $7.1-9$ & 10 & 20 & 12 & 24 \\
\hline $9.1-11$ & 38 & 76 & 36 & 72 \\
\hline$>11$ & 2 & 4 & 1 & 2 \\
\hline Total & 50 & $100 \%$ & 50 & $100 \%$ \\
\hline Mean & 10.01 & 9.38 & \\
\hline P value & 0.001 & & \\
\hline
\end{tabular}

Table 8: Mean hematological parameters at the start of therapy and 4 weeks after therapy.

\begin{tabular}{|lllll|}
\hline Parameter & Group A & Group B \\
& Initially & $\begin{array}{l}\text { At 4 } \\
\text { weeks }\end{array}$ & Initially & $\begin{array}{l}\text { At 4 } \\
\text { weeks }\end{array}$ \\
\hline S. iron $(\mu \mathrm{g} / \mathrm{dl})$ & 33.76 & 60.00 & 33.58 & 56.98 \\
\hline TIBC $(\mu \mathrm{g} / \mathrm{dl})$ & 409.60 & 391.88 & 410.18 & 394.75 \\
\hline MCV $(\mathrm{fl})$ & 61.88 & 63.39 & 61.23 & 62.93 \\
\hline MCH $(\%)$ & 28.49 & 29.88 & 28.60 & 29.71 \\
\hline MCHC $(p g)$ & 24.08 & 26.29 & 23.76 & 24.46 \\
\hline
\end{tabular}

Table 9: Adverse effects in both the groups.

\begin{tabular}{|lllll|}
\hline & Group A & \multicolumn{2}{l|}{ Group B } \\
\hline No. & \% & No. & \% \\
\hline Injection site reaction & 1 & 2 & 2 & 4 \\
\hline Rash & 1 & 2 & 2 & 4 \\
\hline Abdominal pain & - & - & - & - \\
\hline Constipation, diarrhea & - & - & - & - \\
\hline $\begin{array}{l}\text { Hypersensitivity reaction } \\
\text { including anaphylacoid } \\
\text { reaction, hypertension, } \\
\text { hypotension }\end{array}$ & - & - & - & - \\
\hline Headache & 3 & 6 & 4 & 8 \\
\hline Nausea & 1 & 2 & 2 & 4 \\
\hline Total & 6 & 100 & 10 & 100 \\
\hline
\end{tabular}

In group A, $84 \%$ cases achieved the target hemoglobin at 8 weeks after therapy and $100 \%$ cases achieved target hemoglobin at 12 weeks after therapy. In group B, $80 \%$ cases achieved the target hemoglobin at 8 weeks after 
therapy and $98 \%$ cases achieved target hemoglobin at 12 weeks after therapy. In group A $92 \%$ cases were completely relieved of their symptoms at 4 weeks after therapy and in group B only $84 \%$ cases were completely relieved of their symptoms. In group A only $12 \%$ cases had grade I adverse effects and in group B $20 \%$ cases had grade I adverse effects.

None of the case in both the groups had grade II adverse effects. So we can say that the intravenous iron carboxymaltose therapy is more effective and safe therapy to treat iron deficiency anemia during postpartum period.

\section{DISCUSSION}

In obstetrics, red blood cell transfusions currently account for $3-4 \%$ of all transfusion events and the majority of these occur following Post-Partum Hemorrhage (PPH) in $\mathrm{UK}^{9}{ }^{9} \mathrm{PPH}$ is the leading cause of maternal mortality in obstetrics, and is estimated to occur at a rate of $13.1 \%{ }^{10}$ Despite its enormous clinical utility, RBC transfusion is a treatment with well described adverse events and risk, and should ideally be avoided. Additionally blood is both costly and in ever increasingly short supply. ${ }^{11-13}$

In the present study, the cases selected in both the groups were comparable in terms of age, parity, and socioeconomic status. The mean hemoglobin level achieved and rate of increase in intravenous iron carboxymaltose group was significantly higher. S. Bhandari also supported that intravenous ferric carboximaltose is cost effective as it significantly reduces need of blood transfusion and its complications. ${ }^{14,15}$

The incidence of adverse effects was also significantly lower in intravenous iron carboxymaltose group in our study. C. Breymann et al. and R. Eneshaliev et al. showed in their study that ferric carboximaltose in iron deficiency anemia in patients of inflammatory bowel disease as well as in obstetrics is quite safe and effective. ${ }^{16,17}$

\section{CONCLUSION}

Thus we can conclude that intravenous iron carboxymaltose therapy is safe, convenient, more effective and faster acting than intravenous iron sucrose therapy for the treatment of severe iron deficiency anemia during postpartum period. ${ }^{18,19}$

Funding: No funding sources

Conflict of interest: None declared

Ethical approval: The study was approved by the institutional ethics committee

\section{REFERENCES}

1. Morrison J, Patel ST, Watson W, Zaidi QR, Mangione A, Goss TF. Assessment of the prevalence and impact of anaemia on women hospitalized for gynaecology condition associated with heavy uterine bleeding. J Repord Med. 2008;53:323-30.

2. Bodnar LM, Cogswell ME, McDonald T. Have we forgotten the significance of postpartum iron deficiency anaemia? Am J Obstet Gynecol. 2005;193:36-44.

3. Broche DE, Gay C, Armand-Branger S, Grangeasse L, Terzibachian JJ. Acute postpartum anaemia. Clinical practice Leberecht a Haberlin F, Eberhard J. anaemia in puerperium; parenteral iron substitution renders erythropoietin therapy dispensable. Geburtshilfe Frauenheilkd.1995;55:167-70.

4. Prewusny KG, Huck R, Huck A, Breymann C. Parenteral iron sucrose complex. $\mathrm{Br} \mathrm{J}$ Nutr. 2002;88:3-10, and interest of intravenous iron. Gynecol Obstet Fertil. 2004;32:613-9.

5. Al-Momen AK, Al-Meshari A, Al-Nuaim L, Saddique A, Abutalin Z, Khashogi T, et al. Intravenous iron sucrose complex in the treatment of iron deficiency anaemia during pregnancy. Eur $\mathbf{J}$ Obstet Gynecol Reprod Biol. 1996;69:121-4.

6. Bayoumeu F, Subiran-Cusset C, Baka NE, Eegagneur H, Monnier-Barbarino P, Laxenaire MC. Iron therapy in iron deficiency anaemia in pregnancy: intravenous route versus oral route. Am J Obstet Gynecol. 2002;186:518-22.

7. Umbreit IH, Conrad, Moore EG, Latocer LF. Iron absorption and cellular transport. Mobi (Ferrin/Paraferic) Paradigm Semin Hematol. 1998;35:13-26.

8. Willianmson C, Love S, Love EM, Conen H, Soldem $\mathrm{K}$, Mclelland DB, et al. Serious hazards of transfusion initiative: analysis of the first two annual reports. BMJ. 1999;319:16-9.

9. Catling S. Blood conservation techniques in obstetrics: a UK perspective. Int J Obstet Anesth. 2007;6(3):241-9.

10. Ferraris VA, Davenport DL, Saha SP, Austin PC, Zwischenberger JB. Surgical outcomes and transfusion of minimal amounts of blood in the operating room. Arch Surg. 2012;147(1):49-55.

11. Greinacher A, Fendrich K, Brzenska R, Kiefel V, Hoffmann W. Implications of demographics on future blood supply: a population-based crosssectional study. Transfusion. 2011;51(4):702-9.

12. Pfenniger A, Schuller C, Christoph P, Surbek D. Safety and efficacy of high-dose intravenous iron carboxymaltose vs. iron sucrose for treatment of postpartum anemia. J Perinat Med. 2012;40(4):397402.

13. World Health Organization. Pregnancy, childbirth, postpartum and newborn care: a guide for essential practice. In: WHO, eds. WHO Guide. Geneva: World Health Organization; 2006. Funk F, Ryle P, Canclini C, Neiser S, Geisser P. The new generation of intravenous iron: chemistry, pharmacology and toxicology of ferric carboxymaltose. Arzneimittel Forsching. 2010;60(6a):345-53. 
14. Bhandari S. efficacy and safety - the need for convenient and cost effective iron therapy in health care. NDT Plus. 2011;4(Suppl 1):i14-9.

15. Bhandari S. Update of a comparative analysis of cost minimization following the introduction of newly available iron therapies in hospital practice. Therapeut Clin Risk Manag. 2011;7:501-9(b).

16. Evestatiev R, Marteau P, Iqbal T, Khalif IL, Stein J, Bokemeyer B, et al. FERGIcor, a randomized controlled trial on ferric carboxymaltose for iron deficiency anaemia in inflammatory bowel disease. Gastroenterology. 2011 Sep;141(3)846-853.e1-2.

17. Breymann C, Gliga F, Bejenariu C, Stirzhova N. Comparative efficacy and safety of intravenous ferric carboxymaltose in the treatment of iron deficiency anaemia. Int J Gynaecol Obstet. 2008;101:67-73.

18. Seid MH, Derman RJ, Baker JB, Banach W, Goldberg C, Rogers R. Ferric carboxymaltose injection in the treatment of postpartum iron deficiency anaemia: a randomized controlled clinical trial. Am J Obstet Gynaecol. 2008;199:435-7.

19. Van Wyck DB, Martens MG, Seid MH, Baker JB, Mangione A. Intravenous ferric carboxymaltose compared with oral iron in the treatment of postpartum anaemia: a randomized controlled trial. Obstet Gynecol. 2007;110:267-78.

DOI: $10.5455 / 2320-1770 . i j r \operatorname{cog} 20150431$

Cite this article as: Verma U, Singh S, Chandra M, Chandra M, Garg R, Singh S, Rajvansh R. To evaluate the efficacy and safety of single dose intravenous iron carboxymaltose verses multidose iron sucrose in postpartum cases of severe iron deficiency anemia. Int $\mathbf{J}$ Reprod Contracept Obstet Gynecol 2015;4:442-6. 